Journal of Applied Pharmaceutical Science Vol. 6 (10), pp. 216-221, October, 2016

Available online at http://www.japsonline.com

DOI: $10.7324 / \mathrm{JAPS} .2016 .601030$

ISSN 2231-3354 (cc) BY-NC-SA

\title{
Antibacterial potential of fungal endophytes isolated from Boerhaavia diffusa L.
}

\author{
Murali Mahadevamurthy ${ }^{1}$, Hema Puttaswamy ${ }^{1}$, Thriveni M. Channappa ${ }^{1}$, Manjula Sidappa ${ }^{1}$, Prathibha Madegowda ${ }^{2}$, \\ Jayaramu S. Chikkamanchegowda ${ }^{2}$, Amruthesh K. Nagaraj ${ }^{1 *}$ \\ ${ }^{1}$ Applied Plant Pathology Laboratory, Department of Studies in Botany, University of Mysore, Manasagangotri, Mysore- 570006, Karnataka, India. \\ ${ }^{2}$ Department of Zoology, Yuvaraja's College, University of Mysore, Mysore- 570 005, Karnataka, India.
}

\section{ARTICLE INFO \\ Article history: \\ Received on: 14/07/2016 \\ Revised on: 09/08/2016 \\ Accepted on: 22/08/2016 \\ Available online: 29/10/2016}

Key words:

Boerhaavia diffusa, fungal

endophytes, antibacterial

activity.

\begin{abstract}
Boerhaavia diffusa L. is widely used for its ethno-medicinal properties. The present study assessed the antibacterial activity of endophytic fungi harbored in this plant. The endophytic fungi isolated belonged to various genera like Aspergillus, Cladosporium, Colletotrichum, Curvularia, Fusarium, Pestalotiopsis and Zygorhynchus and the overall colonization frequency of endophytic fungi was found to be $24 \%$. Among the isolated fungi Aspergillus fumigatus, Cladosporium sphaerospermum, Fusarium sp. and Zygorhynchus sp. showed antibacterial activity in preliminary screening against one or all the test bacteria. Further, after fermentation, the ethyl acetate extracts of the selected endophytic fungi displayed variable antibacterial activity with maximum $54.75 \mathrm{~mm}$ and a minimum $27.50 \mathrm{~mm}$ zone of inhibition against test bacteria in disc diffusion assay. The lowest minimum inhibitory concentration (MIC) was $0.156 \mathrm{mg} \mathrm{ml}^{-1}$ in the broth dilution assay against a $B$. subtilis, S. typhi and Staph. aureus, while it was $0.312 \mathrm{mg} \mathrm{ml}^{-1}$ against $E$. coli which was offered by the ethyl acetate extracts of $A$. fumigatus.
\end{abstract}

\section{INTRODUCTION}

Endophytic fungi are an interesting group of microorganisms associated with the tissues of plants and are often regarded as plant-defending mutualists (Saikkonen et al., 2004). Plant endophytic fungi are defined as the fungi that spend the whole or part of their life cycle colonizing inside the healthy tissues of the host plant, typically causing no apparent symptoms of disease (Rodriguez et al., 2009) and these fungal endophytes lie under the widely neglected component of plant communities. Endophytic fungi are distributed world-wide and have been isolated from a variety of plant types including mosses, liverworts, ferns and higher plants (Higgins et al., 2007; Rosa et al., 2010; U'Ren et al., 2012). Endophytic fungi have diverse application as they may play role in plant growth (Mucciarelli et al., 2003); plant defense (Gao et al., 2010); affect

\footnotetext{
* Corresponding Author

Dr. K. N. Amruthesh, Applied Plant Pathology Laboratory Department of Studies in Botany University of Mysore, Manasagangotri, Mysore 570 006, India. Phone No: +910821 2419760; Fax No: +910821

2419759; Email: dr.knamruthesh @ botany.uni-mysore.ac.in
}

plant resistance under stressful conditions (both biotic and abiotic stresses) (Marquez et al., 2007; Rodriguez et al., 2008); decompose plant litter (Sun et al., 2011). Apart from these, endophytic fungi are also known to produce many valuable bioactive metabolites including anti-microbial, anti-insect, anticancer, anti-diabetic and immunosuppressant compounds along their great potential applications in agriculture, medicine and food industry (Verma et al., 2009; Zhou et al., 2010; Zhao et al., 2011; Hema et al., 2015). There are various reports on fungal endophytes that produce biologically active compounds including fungicidal and herbicidal properties (Petersen et al., 2004).

The probability of sampling specific medicinal plants that harbor antibiotic producing endophytes might increase significantly if one is guided by the medicinal role of native people (Raviraja et al., 2006). Hence, there is need to isolate new antimicrobial compounds from endophytic fungi that can overcome the difficulties related to the treatment of infections caused by resistant pathogens. Thus, in the present study endophytic fungi associated with Boerhaavia diffusa L.- a medicinal plant with high medicinal properties was screened for their antibacterial potential against test pathogens. 


\section{MATERIALS AND METHODS}

\section{Collection of plant material}

Healthy (showing no visual disease symptoms) mature stem of Boerhaavia diffusa L. were collected from Mysore region, Karnataka. For sampling selection, the plant was randomly collected from different sites in the same vicinity for the study. The healthy stems of the plant were collected and brought to the laboratory and processed immediately to reduce the risk of contamination.

\section{Isolation and identification of endophytic fungi}

The collected plant samples were washed thoroughly 2-3 times in running tap water to remove the dust and debris present on the surface of explants, followed by repeated washing in distilled water. After proper washing, stem samples were cut into small pieces ( 1 to $2 \mathrm{~cm}$ length) under aseptic conditions using sterile scalpel. Further, they were subjected to surface sterilization by immersing the plant samples in $70 \%$ ethyl alcohol for one minute, followed by immersion in $4 \%$ sodium hypochlorite solution for three minutes and then rinsed with deionized sterile distilled water three times to remove the sterilants present on the explants and blot dried on sterile blotter sheets. The efficiency of surface sterilization procedure was ascertained for every segment of tissue following the imprint method of Schulz et al. (1993). About 08 to 10 stem segments were placed on Petri plates containing $20 \mathrm{ml}$ of potato dextrose agar (PDA) medium supplemented with antibiotic chloramphenicol to avoid the emergence of endophytic bacteria. Then the Petri plates were sealed using para film and incubated at $25 \pm 2^{\circ} \mathrm{C}$ for 15 days. Endophytic fungal colonies emerging from their host were picked with sterile fine tip needle and sub cultured on to Petri plates containing PDA devoid of antibiotic to obtain pure cultures. The fungi were identified based on their morphological, conidial and cultural characters (Barnett and Hunter, 1998). All the fungal isolates were maintained in test tubes and Petri plates on PDA media.

\section{Evaluation of antibacterial activity Test organisms}

All the isolated endophytic fungal isolates were screened for antibacterial activity. The indicator bacteria included both Gram-positive (Staphylococcus aureus MTCC 7443 and Bacillus subtilis MTCC 121) and Gram-negative (Escherichia coli MTCC 7410 and Salmonella typhi MTCC 733) bacteria obtained from Microbial Type Culture Collection and Gene Bank (MTCC), Institute of Microbial Technology, Chandigarh, India and used throughout the study. All the microbial cultures were adjusted to 0.5 McFarland standards, which is visually comparable to a microbial suspension of approximately $1.5 \times 10^{8} \mathrm{cfu} \mathrm{ml}^{-1}$.

\section{Preliminary screening}

The preliminary screening of antibacterial activity was carried out done following agar plug method (Devaraju and Satish,
2011). The nutrient agar (NA) medium were poured into Petri plates and inoculated with $100 \mu \mathrm{l}$ of the bacterial suspension and spread uniformly. The mycelial discs $(6 \mathrm{~mm})$ of each endophytic fungal isolate (15 day-old) grown on PDA were obtained from actively growing margins using a sterile cork borer and placed on the surface of the NA medium previously seeded with test organisms. PDA media (6 mm discs) devoid of any fungal colony served as negative control. The plates were sealed using Para film and incubated at $37^{\circ} \mathrm{C}$ for $24 \mathrm{~h}$. After incubation, antibacterial activity was confirmed by the visualization and measurement of inhibition zones. Each experiment was carried out in triplicates and measured diameters of zone of inhibition surrounding the agar disc were averaged and expressed in milli meter $(\mathrm{mm})$. The mean value of the zone of inhibition was recorded.

\section{Fermentation of endophytic fungi}

The endophytic fungal isolates that offered antibacterial activity in primary screening were subjected to fermentation for metabolite production. Each endophytic fungi (5 -10 discs) were picked from actively growing margins and were fermented in 500 $\mathrm{ml}$ Erlenmeyer flasks containing $250 \mathrm{ml}$ of potato dextrose broth (PDB) for 4-6 weeks at $25 \pm 2^{\circ} \mathrm{C}$ under static conditions devoid of antibiotic. After incubation, the culture broth was filtered through Whatmann No. 1 filter paper to separate fungal mat and the resulting culture filtrate was extracted with equal volume of ethyl acetate in total three times and evaporated to dryness using flash evaporator.

\section{Secondary screening}

The fungal isolates with relatively broader antibacterial spectrum or stronger activities shown in the preliminary assay were selected for secondary assay. The secondary antibacterial screening was done by following disc diffusion method (Elecyinmi, 2007). The resulting crude extract of the fungal isolates were dissolved in ethyl acetate and tested for secondary assay. The test bacteria were seeded onto the surface of NA media and uniformly spread. Each sterile disc $(6 \mathrm{~mm})$ were loaded with $50 \mu \mathrm{l}$ of fungal extract (concentration $1 \mathrm{mg} \mathrm{disc}{ }^{-1}$ ) and $50 \mu \mathrm{l}$ of ethyl acetate and equidistantly placed on NA plates. Streptomycin discs were also placed as standard. The inoculated plates were incubated at $25 \pm 2^{\circ} \mathrm{C}$ for $24 \mathrm{~h}$ and measured for its antibacterial activity by measuring the inhibition zones.

\section{Minimum Inhibitory Concentration (MIC) by Micro broth dilution assay}

Minimal Inhibitory Concentration (MIC) was determined by broth micro-dilution technique according to the method of Sarker et al., (2007). The crude ethyl acetate extracts of selected endophytic fungi were diluted to a concentration of $50 \mathrm{mg} \mathrm{ml}^{-1}$ (stock solution). The 96 well plates were prepared by dispensing $100 \mu \mathrm{l}$ of broth and $100 \mu \mathrm{l}$ of the extract to the first well. A twofold serial dilution was made in the row up to 12 well and final concentrations from well one to 12 were $2.5-0.001 \mathrm{mg} \mathrm{ml}^{-1}$. A 10 $\mu \mathrm{l}$ inoculum suspension of each bacterial strain was added to each 
well. The wells containing nutrient broth with inoculum and solvent served as negative control. The plates were incubated at 37 ${ }^{\circ} \mathrm{C}$ for $24 \mathrm{~h}$ and the absorbance was measured at $620 \mathrm{~nm}$ using micro plate reader. The lowest concentration that inhibited visible growth of the test bacteria was recorded as the MIC based on the readings. The MIC was also detected by adding $10 \mu \mathrm{lwell}^{-1}$ of TTC (2, 3, 5-triphenyl tetrazolium chloride) (Sigma) dissolved in water (TTC $2 \mathrm{mg} \mathrm{ml}^{-1}$ ) and incubated under appropriate conditions for $30 \mathrm{~min}$ (Qaiyami, 2007). Viable organism reduced the dye to pink color. The lowest concentration at which the colour change occurred was taken as the MIC value. All MIC tests were repeated in triplicates.

\section{Statistical Analysis}

Data from three replicates were analyzed for each experiment and analysis of variance (ANOVA) using SPSS Inc. 16.0. Significant effects of treatments were determined by $\mathrm{F}$ values $(P \leq 0.05)$. Treatment means were separated by Tukey's Honestly Significant Differences (HSD) test.

\section{RESULTS}

\section{Isolation and identification of endophytic fungi}

A total of 12 endophytic fungi were isolated from healthy stem segments of $B$. diffusa. The overall colonization frequency of endophytic fungi was found to be $24 \%$. The isolated endophytic fungi were classified into seven different taxa of Zygorynchus sp., Pestalotiopsis sp., Fusarium sp., Aspergillus sp., Cladosporium sp., Colletotrichum sp., and Curvularia sp. Among the isolated fungi, Cladosporium sphaerospermum was the dominant fungus showing $25 \%$ of colonization frequency, followed by Fusarium oxysporum (16.6\%) and all the other isolated fungi had a colonization frequency of $8.3 \%$ (Table 1 ).

\section{Evaluation of antibacterial activity Preliminary screening}

All the isolated endophytic fungi were screened for their antibacterial activity against test bacteria by agar plug method. Among the isolated endophytic fungi, Aspergillus fumigatus, Cladosporium sphaerospermum, Fusarium sporotrichioides, Fusarium sp., Zygorhynchus sp. possessed inhibitory activities against one or more test organisms, while other test endophytic fungi had no antibacterial activity. A. fumigatus showed a maximum inhibition zone of $25 \mathrm{~mm}$ against Staph. aureus followed by Fusarium sp. which offered $16 \mathrm{~mm}$ zone of inhibition. Likewise, maximum inhibition zone of 13,15 and $15 \mathrm{~mm}$ against $B$. subtilis, E. coli and $S$. typhi, respectively was observed in Fusarium sp. (Table 2).

Table 1: List of endophytic fungi isolated from of $B$. diffusa.

\begin{tabular}{|c|c|c|c|}
\hline Endophytic fungi & No. of isolates & Colonization rate* $(\%)$ & Dominant fungi (\%) \\
\hline Aspergillus fumigatus & 01 & 02 & 8.3 \\
\hline Cladosporium sphaerospermum & 03 & 06 & 25.0 \\
\hline Colletotrichum sp. & 01 & 02 & 8.3 \\
\hline Curvularia eragrostidis & 01 & 02 & 8.3 \\
\hline Fusarium oxysporum & 02 & 04 & 16.6 \\
\hline Fusarium sporotrichioides & 01 & 02 & 8.3 \\
\hline Fusarium sp. & 01 & 02 & 8.3 \\
\hline Pestalotiopsis guepini & 01 & 02 & 8.3 \\
\hline Zygorhynchus sp. & 01 & 02 & 8.3 \\
\hline No. of isolates & 12 & $24 \%$ & \\
\hline
\end{tabular}

*Based on 50 plant segments plated.

Table 2: Antibacterial activity of isolated endophytic fungi against test bacteria by agar plug method (Zone of inhibition in mm).

\begin{tabular}{|c|c|c|c|c|}
\hline \multirow[t]{2}{*}{ Endophytic fungi } & \multicolumn{4}{|c|}{ Test Bacteria } \\
\hline & Bacillus subtilis & Staphylococcus aureus & Escherichia coli & Salmonella typhi \\
\hline Aspergillus fumigatus & $0.00 \pm 0.00^{\mathrm{c}}$ & $25.00 \pm 0.40^{b}$ & $11.00 \pm 0.40^{\mathrm{c}}$ & $13.00 \pm 0.40^{\mathrm{d}}$ \\
\hline Cladosporium sphaerospermum & $12.75 \pm 0.47^{\mathrm{b}}$ & $0.00 \pm 0.00^{\mathrm{d}}$ & $15.25 \pm 0.25^{\mathrm{b}}$ & $0.00 \pm 0.00^{\mathrm{e}}$ \\
\hline Colletotrichum sp. & $0.00 \pm 0.00^{\mathrm{c}}$ & $0.00 \pm 0.00^{\mathrm{d}}$ & $0.00 \pm 0.00^{\mathrm{d}}$ & $0.00 \pm 0.00^{\mathrm{e}}$ \\
\hline Curvularia eragrostidis & $0.00 \pm 0.00^{\mathrm{c}}$ & $0.00 \pm 0.00^{\mathrm{d}}$ & $0.00 \pm 0.00^{\mathrm{d}}$ & $0.00 \pm 0.00^{\mathrm{e}}$ \\
\hline Fusarium oxysporum & $0.00 \pm 0.00^{\mathrm{c}}$ & $0.00 \pm 0.00^{\mathrm{d}}$ & $0.00 \pm 0.00^{\mathrm{d}}$ & $0.00 \pm 0.00^{\mathrm{e}}$ \\
\hline Fusarium sporotrichioides & $0.00 \pm 0.00^{\mathrm{c}}$ & $0.00 \pm 0.00^{\mathrm{d}}$ & $0.00 \pm 0.00^{\mathrm{d}}$ & $0.00 \pm 0.00^{\mathrm{e}}$ \\
\hline Fusarium sp. & $13.25 \pm 0.62^{b}$ & $16.00 \pm 0.40^{\mathrm{c}}$ & $15.00 \pm 0.40^{\mathrm{b}}$ & $15.00 \pm 0.40^{\mathrm{b}}$ \\
\hline Pestalotiopsis guepini & $0.00 \pm 0.00^{c}$ & $0.00 \pm 0.00^{\mathrm{d}}$ & $0.00 \pm 0.00^{\mathrm{d}}$ & $0.00 \pm 0.00^{\mathrm{e}}$ \\
\hline Zygorhynchus sp. & $12.25 \pm 0.25^{\mathrm{b}}$ & $0.00 \pm 0.00^{\mathrm{d}}$ & $11.00 \pm 0.40^{\mathrm{c}}$ & $14.00 \pm 0.40^{\mathrm{c}}$ \\
\hline Positive control (Streptomycin $50 \mu \mathrm{g} /$ disc) & $32.00 \pm 0.40^{\mathrm{a}}$ & $26.00 \pm 0.40^{\mathrm{a}}$ & $28.00 \pm 0.40^{\mathrm{a}}$ & $29.00 \pm 0.40^{\mathrm{a}}$ \\
\hline Negative control (PDA Agar plug) & $0.00 \pm 0.00^{\mathrm{c}}$ & $0.00 \pm 0.00^{\mathrm{d}}$ & $0.00 \pm 0.00^{\mathrm{d}}$ & $0.00 \pm 0.00^{\mathrm{e}}$ \\
\hline
\end{tabular}

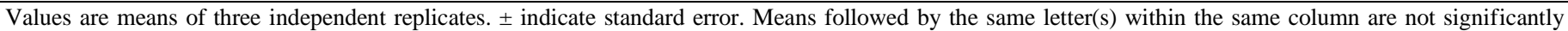
different according to Tukey's HSD. 
Table 3: Antibacterial activity of ethyl acetate extracts of selected endophytic fungi against test bacteria by disc diffusion assay (Zone of inhibition in mm). Endophytic fungi

\begin{tabular}{|c|c|c|c|c|}
\hline & Bacillus subtilis & Staphylococcus aureus & Escherichia coli & Salmonella typhi \\
\hline Aspergillus fumigatus & $37.75 \pm 0.47^{\mathrm{a}}$ & $34.75 \pm 0.25^{\mathrm{a}}$ & $32.00 \pm 0.40^{\mathrm{a}}$ & $44.25 \pm 0.47^{\mathrm{c}}$ \\
\hline Cladosporium sphaerospermum & $30.25 \pm 0.47^{\mathrm{c}}$ & $28.25 \pm 0.47^{\mathrm{c}}$ & $27.50 \pm 0.50^{\mathrm{b}}$ & $27.75 \pm 0.47^{\mathrm{e}}$ \\
\hline Fusarium sp. & $28.50 \pm 0.64^{\mathrm{c}}$ & $31.50 \pm 0.50^{\mathrm{b}}$ & $28.00 \pm 0.57^{b}$ & $54.75 \pm 0.62^{\mathrm{a}}$ \\
\hline Zygorhynchus sp. & $30.25 \pm 0.47^{\mathrm{c}}$ & $28.75 \pm 0.47^{\mathrm{c}}$ & $28.50 \pm 0.28^{b}$ & $48.75 \pm 0.47^{\mathrm{b}}$ \\
\hline Streptomycin & $32.25 \pm 0.47^{\mathrm{b}}$ & $28.00 \pm 0.40^{\mathrm{c}}$ & $29.00 \pm 0.40^{\mathrm{b}}$ & $29.50 \pm 0.28^{\mathrm{d}}$ \\
\hline Negative control & $0.00 \pm 0.00^{\mathrm{d}}$ & $0.00 \pm 0.00^{\mathrm{d}}$ & $0.00 \pm 0.00^{\mathrm{c}}$ & $0.00 \pm 0.00^{\mathrm{f}}$ \\
\hline
\end{tabular}

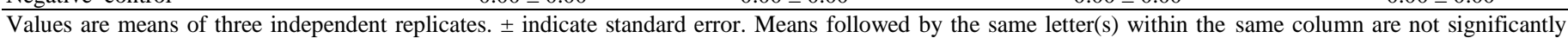
different according to Tukey's HSD.

Table 4: MIC of ethyl acetate extracts of selected endophytic fungi against test bacteria $\left(\mathrm{mg} \mathrm{ml}^{-1}\right)$.

\begin{tabular}{ll}
\hline Endophytic fungi & Baci \\
\cline { 2 - 3 } Aspergillus fumigatus & Cladosporium sphaerospermum \\
Fusarium sp. \\
Cygorhynchus sp. \\
Control (Streptomycin) \\
\hline
\end{tabular}
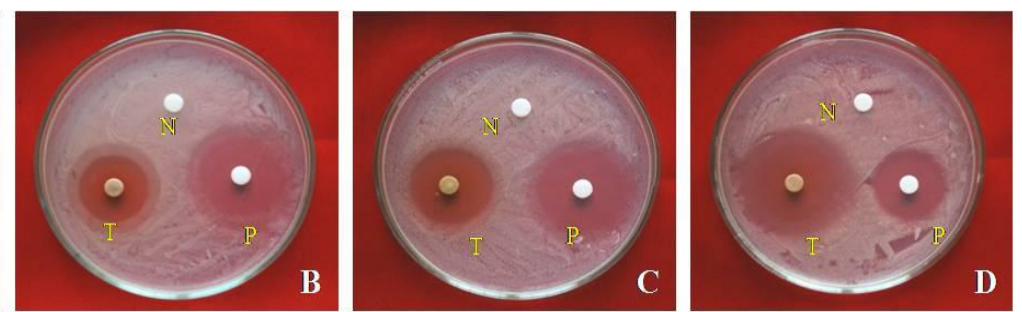

\section{Extract of Aspergillus fumigatus}
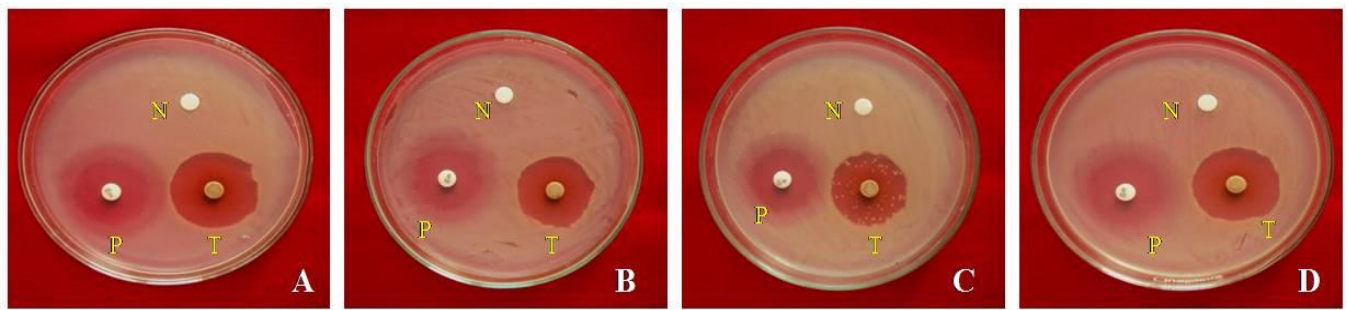

\section{Extract of Cladosporium sphaerospermum}
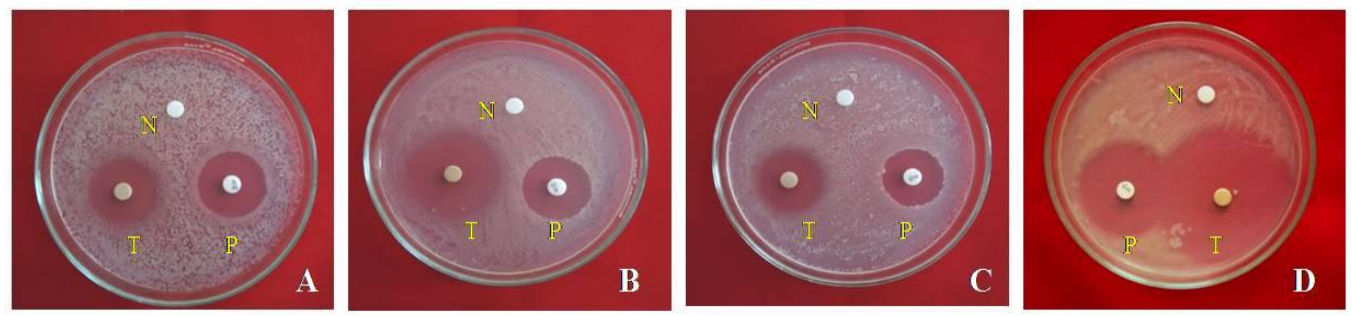

\section{Extract of Fusarium sp.}
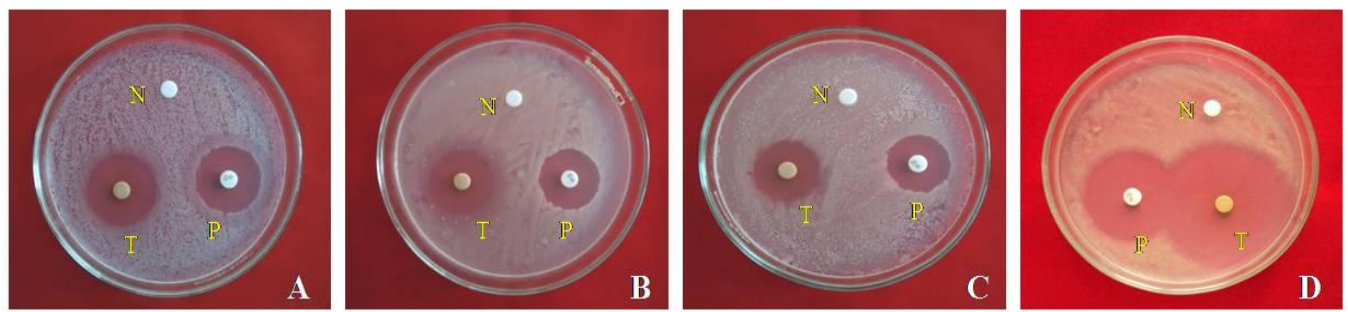

Extract of Zygorhynchus sp.

Fig. 1: Antibacterial activity of ethyl acetate extracts of selected endophytic fungi against test pathogens by disc diffusion method. A: B. subtilis; B: Staph. aureus; C: E. coli; D: S. typhi; N: Negative control; P: Positive control; T: Treatment. 


\section{Secondary screening}

The fungal isolates that showed antibacterial activity in primary screening were subjected to aerobic liquid fermentation and tested for its potential against test pathogens by disc diffusion method. The selected endophytic fungi that had offered antibacterial activity against one or all test pathogens in primary screening, but when subjected for secondary screening by using ethyl acetate extract showed significant antibacterial activity against all the test pathogens. Among the test endophytic fungi maximum inhibition zone against all the test pathogen was offered by the crude ethyl acetate extracts of A. fumigatus, followed by Zygorhynchus sp. and C. sphaerospermum extracts, respectively (Table 3).

\section{Minimum Inhibitory Concentration (MIC) by Micro broth dilution assay}

All the ethyl acetate extracts of selected fungi were further subjected for MIC as they offered significant antibacterial activity against test pathogens. The MIC of the crude ethyl extracts varied in the range of 0.156 to $0.625 \mathrm{mg} \mathrm{ml}^{-1}$ (Table 4). The results of the study revealed that $0.156 \mathrm{mg} \mathrm{ml}^{-1}$ of the extract was more than enough to inhibit B. subtilis, S. aureus and $S$. typhi, while $0.312 \mathrm{mg} \mathrm{ml}^{-1}$ of the extract was required to inhibit E. coli. Among the test ethyl extracts, A. fumigatus had minimum MIC value of $0.156 \mathrm{mg} \mathrm{ml}^{-1}$, while the extracts of Fusarium sp. showed highest MIC values with $0.625 \mathrm{mg} \mathrm{ml}^{-1}$ against test bacteria.

\section{DISCUSSION}

Endophytes are garnering increased attention because they are ubiquitous and posses to have varied roles including protection to host plants against various pathogens and herbivores and potential to produce bioactive compounds (Arnold et al., 2003; Strobel, et al., 2004; Schulz and Boyle, 2005; Saikkonen et al., 2006; Rudgers et al., 2007). The present day research is focused on isolating novel compounds of biological importance from endophytic fungi as they are unexplored to a greater extent. In the present study, the diverse endophytic population was detected to colonize $B$. diffusa. A total of twelve endophytic fungi belonging to six different genera were isolated. The overall colonization frequency was determined as $24 \%$ in surface sterilized tissues. Among the endophytic fungal population, Cladosporium sphaerospermum was the most dominant endophyte in $B$. diffusa. Likewise, many endophytic fungi have been isolated from other plant species (Saikkonen et al., 2006; Rudgers et al., 2007).

Microbial endophytes are considered as a promising source for producing a variety of antimicrobial compounds and numerous attempts have been made to isolate and identify bioactive metabolites from endophytic fungi by researchers (Strobel et al., 2004; Saikkonen et al., 2006; Rudgers et al., 2007). In the present study, all the isolated endophytic fungi were subjected for preliminary antibacterial screening by agar plug method against four potent pathogens. The results of the study revealed that a total of four endophytic fungi were able to inhibit the growth of one or all the test pathogens (Table 1) which is significantly higher as $33 \%$ of isolated endophytic fungi offered antibacterial activity. The results corroborate with that of Gong and Guo (2009) where a total of $8.3 \%$ of endophytic fungi isolated from Dracaena cambodiana and Aquilaria sinensis showed antimicrobial activity. It is interesting that four endophytic fungi, Aspergillus fumigatus, Cladosporium sphaerospermum, Fusarium sp. and Zygorhynchus sp. inhibited the growth of at least two of the four pathogens (50\%), showing their broad spectrum antibacterial activity. There are reports on antimicrobial and cytotoxicity potential of various groups of endophytic fungi isolated from different hosts (Kharwar et al., 2011).

Further, the ethyl acetate extract of the selected fungi were subjected for their antibacterial potential by disc diffusion method. The results offered greater antibacterial potential when the crude ethyl extracts were used. The results obtained may be ascribed for their antimicrobial potential of the extract or due to the high concentration of unidentified active principle present in them. The results are in agreement with earlier studies, wherein the crude extracts of endophytic fungi have yielded more potent compounds that offer greater antimicrobial activity once they had undergone some purification (Fabry et al., 1998; Devi et al., 2012).

From the MIC study, it has been observed that the endophytic fungi extract exhibited activity against tested bacteria (both Grampositive and Gram-negative). All the crude extracts of endophytic fungi presented significant antibacterial activity against the test pathogens. The MIC value of the extracts ranged from 0.156 to $0.625 \mathrm{mg} \mathrm{ml}^{-1}$. Among the test endophytic extracts, A. fumigatus was highly active against all the test pathogens when compared to other extracts (Table 4). However, many studies have shown that several endophytic fungi isolated from Paris polyphylla var. yunnanensis, Acanthus ilicifolius and Acrostichum aureum showed broad spectrum antimicrobial activity (Maria et al., 2005; Zhao et $a l ., 2010)$. The results of the study have highlighted that the ethyl acetate extracts of selected endophytic fungi may have a relatively high proportion of active antibacterial compounds against test bacterial pathogens. The overall findings of this study denote that Boerhaavia diffusa was sampled for the first time to isolate endophytic fungi, and interestingly the plant harbored good diversity with greater antibacterial activity. The endophytic fungi isolated from the host $B$. diffusa and their promising antibacterial activity against test pathogens may lead to identify active principle present in them.

\section{ACKNOWLEDGEMENT}

The authors are grateful to DST- FIST, IOE, UGC and CSIR, Govt. of India, New Delhi for providing facilities.

Conflict of Interests: There are no conflicts of interest. 


\section{REFERENCES}

Arnold AE, Mejia LC, Kyllo D, Rojas EI, Maynard Z, Robbins $\mathrm{N}$, Herre EA. Fungal endophytes limit pathogen damage in a tropical tree. Proc. Natl. Acad. Sci. 2003; 100(26):15649-15654.

Barnett HL, Hunter BB. 1998. Illustrated Genera of Imperfect Fungi. APS Press, St. Paul, Minnesota, USA.

Devaraju R, Satish S. Endophytic Mycoflora of Mirabilis jalapa L. and studies on antimicrobial activity of its endophytic Fusarium sp. Asian J. Exp. Biol. Sci. 2011; 2(1):75-79.

Devi NN, Prabhakaran JJ, Wahab F. Phytochemical analysis and enzyme analysis of endophytic fungi from Centella asiatica. Asian Pac. J. Trop. Biomed. 2012; 2(3):1-5.

Elecyinimi, AF. Chemical composition and antibacterial activity of Gonginarium latifolium. J. Zhejiang Univ. Sci. B. 2007; 8:352-358.

Fabry W, Okemo PO, Ansorg R. Antibacterial activity of East African medicinal plants. J Ethnopharmacol. 1998; 60:79-84.

Gao FK, Dai CC, Liu XZ. Mechanism of fungal endophytes in plant protection against pathogen. Afr. J. Microbiol. Res. 2010; 4(13):1346-1351.

Hema P, Murali M, Thriveni MC, Prathibha M, Jayaramu SC, Amruthesh KN. Phytochemical Analysis and Antibacterial Activity of Endophytic Fungi Isolated from Basella rubra L.-A Medicinal Plant. J of Pure and Appl. Microbiol. 2015; 9(4):2971-2978.

Higgins KL, Arnold AE, Miadlikowska J, Sarvate SD, Lutzoni F. Phylogenetic relationships, host affinity, and geographic structure of boreal and arctic endophytes from three major plant lineages. Mol. Phylogenet. Evol. 2007; 42:543-555.

Kharwar RN, Mishra A, Gond SK, Stierle A, Stierle D. Anticancer compounds derived from fungal endophytes: their importance and future challenges. Nat. Prod. Rep. 2011; 28:1208-1228.

Maria GL, Sridhar KR, Raviraja NS. Antimicrobial and enzyme activity of mangrove endophytic fungi of southwest coast of India. J. Agri. Tech. 2005; 1:67-80.

Marquez LM, Redman RS, Rodriguez RJ, Roossinck MJ.A virus in a fungus in a plant: three way symbiosis required for thermal tolerance. Science. 2007; 315:513-515.

Mucciarelli M, Scannerini S, Bertea C, Maffei M. In vitro and in vivo peppermint (Mentha piperita) growth promotion by nonmycorrhizal fungal colonization. New Phytol. 2003; 158:579-591.

Petersen PJ, Wang TZ, Dushin RG, Bradford PA. Comparative in vitro activities of AC98-6446, a novel semisynthetic glycopeptide derivative of the natural product mannopeptimycin $\alpha$, and other antimicrobial agents against gram-positive clinical isolates. Antimicrob. Agents Chemother. 2004; 48(3):739-746.

Qaiyami S. 2007. Macro and Microdilution methods of antimicrobial susceptibility Testing. In: Schwalbe R, Steele-Moore L, Goodwin AC (eds.) Antimicrobial Susceptibility Testing Protocols. New York, Taylor \& Francis Group. pp. 75-81.

Raviraja NS, Maria GL, Sridhar KR. Antimicrobial evaluation of endophytic fungi inhabiting medicinal plants of the Western ghats of India. Eng. Life Sci., 2006; 6:515-520.
Rodriguez RJ, Henson J, van Volkenburgh E, Hoy M, Wright L, Beckwith F, Kim YO, Redman RS. Stress tolerance in plants via habitatadapted symbiosis. ISME J. 2008; 2: 404-416.

Rodriguez RJ, White JF, Arnold AE, Redman RS. Fungal endophytes: Diversity and functional roles. New Phytol. 2009; 182: $314-$ 330 .

Rosa LH, Almeida Vieira Mde L, Santiago IF, Rosa CA. Endophytic fungi community associated with the dicotyledonous plant Colobanthus quitensis (Kunth) Bartl. (Caryophyllaceae) in Antarctica. FEMS Microbiol. Ecol. 2010; 73:178-189.

Rudgers JA, Holah J, Orr SP, Clay K. Forest succession suppressed by an introduced plant-fungal symbiosis. Ecology. 2007; 88:18-25.

Saikkonen K, Lehtonen P, Helander M, Koricheva J, Faeth SH. Model systems in ecology: dissecting the endophyte-grass literature Trends Plant Sci. 2006; 11:428-433.

Saikkonen K, Wali P, Helander M, Faeth SH. Evolution of endophyte-plant symbiosis. Trends Plant Sci. 2004; 9: 275-280.

Sarker SD, Nahar L, Kumarasamy Y. Microtitre plate based antibacterial assay incorporating resazurin as an indicator of cell growth, and its application in the in vitro antibacterial screening of phytochemicals. Methods. 2007; 42:321-324.

Schulz B, Boyle C. The Endophytic Continuum. Mycol Res. 2005; 109(6):661-686.

Schulz B, Wanke U, Draeger S. Endophytes from herbaceous and shrubs: effectiveness of surface sterilization methods. Mycol Res 1993; 97:1447-1450.

Strobel G, Daisy B, Castillo U, Harper J. Natural products from endophytic microorganisms. J. Nat. Prod. 2004; 67(2):257-268.

Sun X, Guo LD, Hyde KD. Community composition of endophytic fungi in Acer truncatum and their role in decomposition Fungal Divers. 2011; 47:85-95.

U'Ren JM, Lutzoni F, Miadlikowska J, Laettsch AD, Arnold AE. Host and geographic structure of endophytic and endolichenic fungi at a continental scale. Am. J. Bot. 2012; 99:898-914.

\section{How to cite this article:}

Murali, M., Hema, P., Thriveni, M.C., Manjula, S., Prathibha, M., Jayaramu, S.C. and Amruthesh, K.N. Antibacterial potential of fungal endophytes isolated from Boerhaavia diffusa L. J App Pharm Sci, 2016; 6 (10): 216-221. 